\title{
Potter Wasps of Florida, Eumenes spp. (Insecta: Hymenoptera: Vespidae: Eumeninae) ${ }^{1}$
}

\author{
E. E. Grissell ${ }^{2}$
}

\section{Introduction}

Currently there are eight species and 10 subspecies of Eumenes known in America north of Mexico. Only E. fraternus Say and the nominate subspecies of E. smithii Saussure occur in Florida. These wasps make the familiar jug-like mud nests found on buildings, window sills, screens, and shrubs around the home. Members of the subfamily Eumenidae may be identified to genus with the aid of a key in Parker (1966). The only key for identifying North American species of Eumenes is that of Isley (1917) which is somewhat out of date.

\section{Distribution}

E. fraternus occurs from about the 100 meridian eastward in the United States and Canada. The nominate subspecies of $E$. smithii is found in the southern states from Mississippi eastward and North Carolina southward. The subspecies E. smithii belfragei Cresson occurs from Mexico northward through eastern Texas, Oklahoma, Kansas, and eastward to Missouri and Arkansas. 
nest of E. smithii may be distinguished from that of $E$. fraternus by the more granular and roughened surface due to small lumps of earth. This observation was based on one nest, however, and is probably not a consistent difference.

Adults: Eumenes have a characteristic appearance. Adults are 13 to $17 \mathrm{~mm}$ in length (Arnett 2000). The first abdominal segments are rather elongate (i.e., petiolate), increasing gradually in width posteriorly from point of attachment at the thorax. One other genus of eumenid wasp (Zethus) could easily be confused with Eumenes, but it has the second abdominal segment more petiolate and the posterior margin of the second submarginal cell truncate whereas Eumenes has the cell acute.


Figure 2. Eumenes wing (A) and abdomen (B). Credits: Division of Plant Industry
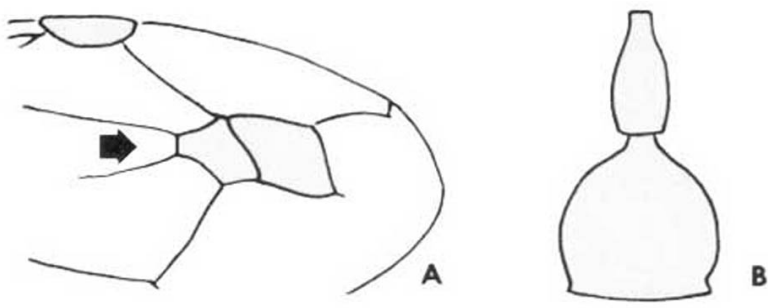

Figure 3. Zethus wing $(A)$ and abdomen (B). Credits: Division of Plant Industry

\section{Biology}

Little detailed information is available on the biology of any North American species of Eumenes. The habits of $E$. smithii are essentially unknown, whereas $E$. fraternus has had only fragmentary consideration. Say (1824) noted that an adult $E$. fraternus emerged through the side of its clay pot in July. Isley (1914) reported and illustrated two nests of E. fraternus from a dogwood limb in Kansas. The nests were found in March and adult wasps emerged in May. The two earth pots were attached to each other so that one lateral wall served for both. Isley (1917) listed some of the fragmentary references to this species. Arnett (2000) states that the adults fly from June to October to visit flowers to gather moth and beetle larvae, and that the female's eggs are suspended from slender threads attached to the top of sides of the pot.

Little detailed information is available on the biology of any North American species of Eumenes. The habits of E. smithii are essentially unknown, whereas $E$. fraternus has had only fragmentary consideration. Say (1824) noted that an adult $E$. fraternus emerged through the side of its clay pot in July. Isley (1914) reported and illustrated two nests of E. fraternus from a dogwood limb in Kansas. The nests were found in March and adult wasps emerged in May. The two earth pots were attached to each other so that one lateral wall served for both. Isley (1917) listed some of the fragmentary references to this species. Arnett (2000) states that the adults fly from June to October to visit flowers to gather moth and beetle larvae, and that the female's eggs are suspended from slender threads attached to the top of sides of the pot.

\section{Economic Importance}

As with many wasps, destruction of insects that attack cultivated and ornamental plants far outweighs the few mud pots one might find on one's home or in one's garden. The occasional nests which are found may be scraped off with any blade-like object. No wasp will buzz out to sting the destructor.

\section{Selected References}

Arnett Jr RH. 2000. American Insects: A Handbook of the Insects of America North of Mexico. CRC Press. Boca Raton. 1003 pp.

Isley D. 1914. The biology of some Kansas Eumenidae. Kansas University Science Bulletin 8: 233-309.

Isley D. 1917. A synopsis of the petiolate wasps of the family Eumenidae (Hymenoptera), found in America north of Mexico. Annals of the Entomological Society of America 10: 345-366.

Iwata K. 1953. Biology of Eumenes in Japan. Mushi 25: 25-46. 
Linsley EG. 1962. Sleeping aggregations of aculeate Hymenoptera.--II. Annals of the Entomological Society of America 55: 148-164.

Parker FD. 1966. A revision of the North American species in the genus Leptochilus (Hymenoptera: Eumenidae). Miscellaneous Publications of the Entomological Society of America. 5: 151-229.

Say T. 1824. In Keating's narrative of an expedition to the source of St. Peter's river, Lake Winnepeck, Lake of the Woods, under the command of Major Long 1823. Philadelphia. Appendix 2. p. 268-378. 